\title{
Hallux valgus korrekció módosított Lapidus mútéttel
}

\author{
DR. SAMU DÉNES, DR. SZABÓ ATTILA, DR. FARKAS CSABA
}

\section{ÖSSZEFOGLALÁS}

A metatarsus primus varus és hallux valgus középsúlyos és súlyos eseteinek mútéti korrekciója nagy kihívást jelent mind első mútéti ellátásként, mind korábbi elégtelen bütyökmútétek revíziójaként. A szerzők ismertetik a hallux valgus kialakulásának patomechanizmusát, klasszifikációját, vizsgálati módszereket. Részletesen bemutatják az általuk alkalmazott módosított Lapidus tarsometatarsalis arthrodesist. 2009 és 2017 között 17 esetben végeztek metatarsocuneiformis desist, 4 alkalommal korábbi insufficiens mütét (Austin osteotomia, basis osteotomia) revíziójaként, 13 esetben primer mútétként. Preoperatív és posztoperatív röntgenfelvételen vizsgálták az intermetatarsalis szög és a hallux valgus szög változását, valamint a szezámcsontok subluxatiójának mértékét. $A z$ intermetatarsalis szög preoperatív értéke $17,6^{\circ}\left(15-24^{\circ}\right)$, posztoperatív $8,2^{\circ}\left(1-10^{\circ}\right)$, míg a hallux valgus szögérték preoperatív $45,3^{\circ}\left(26-70^{\circ}\right)$, posztoperativ $11,7^{\circ}\left(0-25^{\circ}\right)$. A szezámcsontok subluxatiója minden esetben megszúnt. Az AOFAS boka-láb pontrendszerrel értékelve eredményeiket, 46-ról (12-65) 93-ra (88-100) emelkedett. A módosított Lapidus metatarsocuneiformis arthrodesis alkalmasnak bizonyult a súlyos fokú metatarsus primus varussal szövődött hallux valgus mútéti megoldására, valamint az insufficiens mútétek revíziójára is. A szerzók fontosnak tartják kiemelni, hogy a tarsometatarsalis desis mellett minden esetben szükséges a lágyrész balance helyreállítása.

\section{Kulcsszavak: $\quad$ Arthrodesis; Hallux valgus; Lábdeformitás; Ortopédiai eljárások;}

\section{Samu, A. Szabó, Cs. Farkas: Hallux valgus correction with modified Lapidus procedure}

The surgical correction of moderate and severe cases of metatarsus primus varus and hallux valgus is a challenge both as primary surgical treatment and as revision surgery for previous insufficient bunion surgery. The authors describe the pathomechanism of the development of hallux valgus, its classifications and examination methods and provide a detailed description of the modified Lapidus tarsometatarsal arthrodesis they apply. Between 2009 and 2017 metatarsocuneiform arthrodesis was performed in 17 cases: on 4 occasions, revision of previous insufficient surgery (Austin osteotomy, basis osteotomy) and in 13 cases primary surgery. Preoperative and postoperative $\mathrm{X}$-ray pictures were used to examine the deviations of the intermetatarsal angle (IMA) and the hallux valgus angle (HVA) and the grade of the sesamoid subluxation. Preoperative IMA $17.6^{\circ}\left(15-24^{\circ}\right)$, postoperative IMA $8.2^{\circ}\left(1-10^{\circ}\right)$, whereas preoperative HVA $45.3^{\circ}\left(26-70^{\circ}\right)$, postoperative HVA $11.7^{\circ}\left(0-25^{\circ}\right)$. Sesamoid subluxation ceased in all cases. The results were evaluated using the AOFAS Ankle-Hindfoot Score, they improved from 46 (12-65) to 93 (88-100). The modified Lapidus metatarsocuneiform arthrodesis proved to be applicable for the surgical correction of severe metatarsus primus varus associated with hallus valgus and also for revision of insufficient surgery. The authors find it important to emphasize that besides tarsometatarsal desis, the reconstruction of soft-tissue balance is needed in all cases.

Key words:

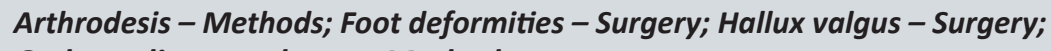




\section{BEVEZETÉS}

Carl Hueter definiálta először azt a lábdeformitást, amely az öregujj lateralis irányú deviációjával, az I. metatarsus medialis irányú eltérésével és a metatarsophalangealis (MTP) ízület statikus subluxatiójával jár. A hallux valgus az orvosi gyakorlatban az egyik leggyakrabban látott lábdeformitás, amely gyakran funkciózavarral és lábfájdalommal társul. Becsült prevalenciája 23\% a 18-65 éves korosztályon belül, míg 35,7\% 65 éves kor felett. Nőkben gyakrabban fordul elő (30\%), mint férfiakban (13\%) (7).

Kialakulásában szerepe van extrinsic (túlsúly, magas sarkú, szűk lábbeli) és intrinsic faktoroknak (genetika, életkor, lúdtalp, szalagok lazasága, I. sugár hypermobilitása) (9). Ezek hatására az I. sugár statikus (ízületi tok, szalagrendszer, plantaris fascia) és dinamikus stabilizátorai ( $m$. peroneus longus, talpi izomzat) között felborul a finom egyensúly (9). Az öregujj lateralis irányba vándorol, hossztengelye körül rotálódik és pronatióba kerül, az I. metatarsus (MT) medialis irányba deviál. Az MTP ízület medialis oldala megnyúlik, míg a lateralis megrövidül, az MTP ízület subluxálódik. A m. abductor hallucisnak megszűnik az abductor hatása és flexorként múködik. A rövid flexorok az adductor izomzat húzásához adódnak. A lateralizált hosszú flexor és extensor inak tovább fokozzák a valgus deformitást (9). A röntgenfelvételen mért intermetatarsalis szög (IMA), hallux valgus szög (HVA) és szezámcsontok subluxatiója alapján osztályozhatjuk az elváltozás súlyosságát (I. táblázat).

A hallux valgus kezelésében mind konzervatív módszereket, mind mútéti megoldásokat alkalmazhatunk. A nem operatív eljárások enyhítik ugyan a panaszokat, de az öregujj deformitását nem tudják korrigálni (16). Sebészi beavatkozástól várható tartós, jó eredmény. Több mint 100 -féle mútéti technika létezik a hallux valgus sebészetében. A helyesen értékelt deformitás és a megfelelő műtéti eljárás kiválasztása nélkülözhetetlen a sikeres beavatkozáshoz (2).

A mútéti stratégia és algoritmus főbb elemeiben a szakirodalom alapvetően egyetért (10). A hallux valgus klasszifikációjának megfelelően választunk mútéti eljárást. Az IMA és HVA növekedésével egyre proximalisabban végezzük az I. MT osteotomiát. Így enyhe esetben distalis lágyrész korrekció, dorsomedialis csontnövedék levéséssel (McBride; Schede), súlyosabb esetekben I. MT subcapitalis (Austin; chevron), diaphysis (Scarf) vagy basis osteotomia (basis nyitó-záró ék ostetomia) a szögértékek és MTP ízületi subluxatio mértékének megfelelően. Ezen mútéti algoritmus végén található az MTC desis (Lapidus). Amenynyiben MTP ízületi arthrosis észlelhető idős, inaktív beteg esetében reszekciós arthroplastica javasolt (Keller-Brandes), míg fiatal, aktív beteg esetében MTP desis a választandó eljárás (10). A mútéteket gondos tervezésnek kell megelőznie, a mütétek végzésénél fontos a kézsebészetből ismert finom, precíz mútéti technika.

Módosított Lapidus mútét során I. MTC ízületi arthrodesist végzünk korrigált helyzetben, majd beállítjuk a lágyrész egyensúlyt az I. MTP ízületben (lateralis release, medialis raffolás). Javasolt minden olyan esetben, amikor az IMA $15^{\circ}$-ot meghaladja, valamint az I. sugár patológiás laxitása esetén.

Jelen tanulmányunkban a módosított Lapidus desis létjogosultságát kívánjuk igazolni középsúlyos és súlyos esetekben, valamint insufficiens hallux mútétek revíziójaként.

\section{I. táblázat A hallux valgus osztályozása}

\begin{tabular}{|c|c|c|c|c|}
\hline & IMA & HVA & $\begin{array}{c}\text { Szezámcsont } \\
\text { subluxatio }\end{array}$ & $\begin{array}{c}\text { MTP } \\
\text { incongruentia }\end{array}$ \\
\hline Normál & $<9^{\circ}$ & $<15^{\circ}$ & - & nincs \\
\hline Enyhe & $9-11^{\circ}$ & $15-20^{\circ}$ & $<50 \%$ & nincs \\
\hline Középsúlyos & $11-16^{\circ}$ & $20-40^{\circ}$ & $50-75 \%$ & van \\
\hline Súlyos & $>16^{\circ}$ & $>40^{\circ}$ & $>75 \%$ & van \\
\hline
\end{tabular}




\section{ANYAG ÉS MÓDSZER}

Az SzSzBMK Jósa András Oktatókórház Ortopédiai Osztályán 2009 augusztusa és 2017 augusztusa között összesen 17 esetben alkalmaztunk módosított Lapidus mútétet. 14 nő és 2 férfibeteg volt, egy esetben kétoldali mútétet végeztünk. $A$ betegek átlagéletkora a mútét időpontjában 53 év (26-72). 13 esetben primer mútéti eljárásként, 4 esetben pedig elégtelen primer korrekciós mútét revíziójaként alkalmaztuk (két subcapitalis Austin osteotomia, két basis osteotomia). 12 beteg a súlyos kategóriába, 4 beteg a középsúlyosba tartozott.

A mútét során minden esetben MTC arthrodesist végeztünk két vagy három keresztezett csavarral. Az esetek kétharmadában az elmerevített ízületben spongiosa plasztika is történt. Az MTP ízületben lateralis tokbemetszést $m$. adductor hallucis leválasztással és medialis tokraffolást, I. MT fej dorsomedialis oldalán lévő csontnövedék levésést, valamint $\mathrm{m}$. abductor hallucis ín felszabadítást és medializálást is végeztünk. Mútét után 6 hétig segédeszközzel (járókeret, könyökmankó) való tehermentesítést javasoltunk, intenzív lábujjtornát végeztek. Hat hét után a teljes súllyal való terhelés megengedett volt.

Preoperativ és posztoperatív kétirányú nem terhelt láb röntgenfelvételeken digitális kalibrált szögmérővel mértük az IMA, HVA értékét, illetve vizsgáltuk a szezámcsontok subluxatiójának javulását és a MTP ízületi kongruencia helyreállását. Posztoperatív 6 hetes és 3 hónapos korban kontrolláltuk a röntgenfelvételeket, és ezt követően évente kontrollra rendeltük vissza a betegeket. A betegek átlagos utánkövetési ideje 20 hónap (2-97 hónap). Eredményeinket a szögértékek alapján valamint az AOFAS boka-láb skálán értékeltük.

\section{MÜTÉTI TECHNIKA}

A mütétet minden esetben subarachnoidealis anesztéziában, hanyatt fekvő helyzetben, képerősítő használata mellett, vértelenségben végezzük. Ívelt hosszanti metszést ejtünk az I. MTP ízülettől a MTC ízületig. Az MTP ízület medialis oldalán lebenyt képzünk, kipreparáljuk az m. abductor hallucis inának tapadását és medialis irányba emeljük elő a talp felöl (1. ábra). Az MT fej dorsalis és medialis felszínén lévő csontnövedéket levéssük, a levésett csontot félretesszük a későbbi spongiosa plasztikához. Az I. interdigitalis redőben ejtett stich incisióból leválasztjuk az m. adductor hallucist, lateralis tok release-t végzünk. Feltárjuk az I. MTC ízületet subperiostalisan haladva, kijelöljük az osteotomia megfelelő helyét. Az I. MT basis reszekciós síkja merőleges az I. MT hossztengelyére, itt tengelykorrekciót nem végzünk, épphogy porctalanítjuk a felszínét (2. ábra). A cuneiforme mediale distalis felszínéből röntgenen kimért ékreszekciót végzünk (3. ábra). Repositiós és arthrodesis fogó segítségével, képerősítő kontrollja alatt beállítjuk a megfelelő tengelyt, majd Kirschner drót segítségével rögzítjük az elért helyzetet. Egy tengelyben vezetett Kirschner drótot alkalmazunk, szükség esetén egy haránt vezetett drótot is használhatunk (4. ábra).

Amennyiben az I. sugár rövidülését észleljük, vagy nem tudjuk megfelelően korrigálni a tengelyállást, úgy a korábban levésett csontot használjuk fel az MTC ízületben. Két vagy három darab $4 \mathrm{~mm}$ átmérőjű $\mathrm{KFI}$ spongiosa csavart használunk. Az első csavart distal felől proximal felé, dorso-plantaris irányba hajtjuk be. A következő́t ezzel keresztezett irányba distal felől planto-dorsalis irányba hajtjuk be. Szükség esetén további egy csavart vezetünk be medial felől a cuneiforme intermediusba (5-6. ábra). A periosteumot zárjuk, majd a medialis MTP ízületi tokot raffoljuk és az abductor ín distalis részét a tok medialis falához rögzítjük, így korrigálva a húzás irányát. 




1. ábra Feltárás és medialis tokraffolás

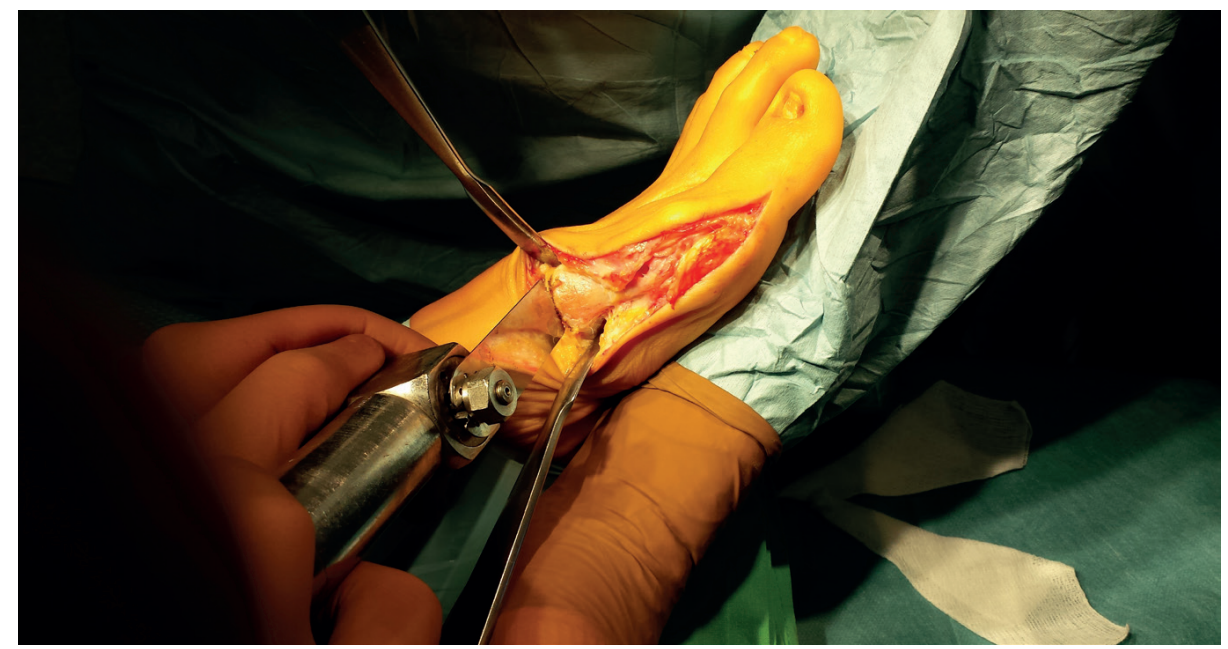

2. ábra I. MT basis reszekció

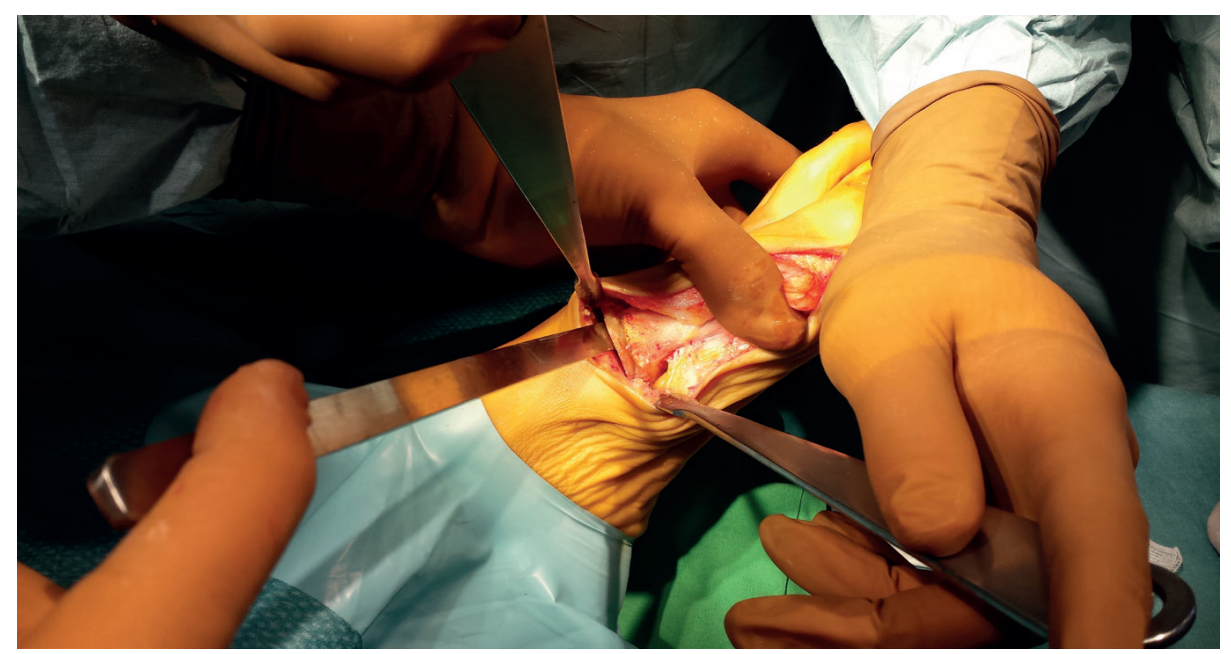

3. ábra Cuneiforme mediale ék reszekció 


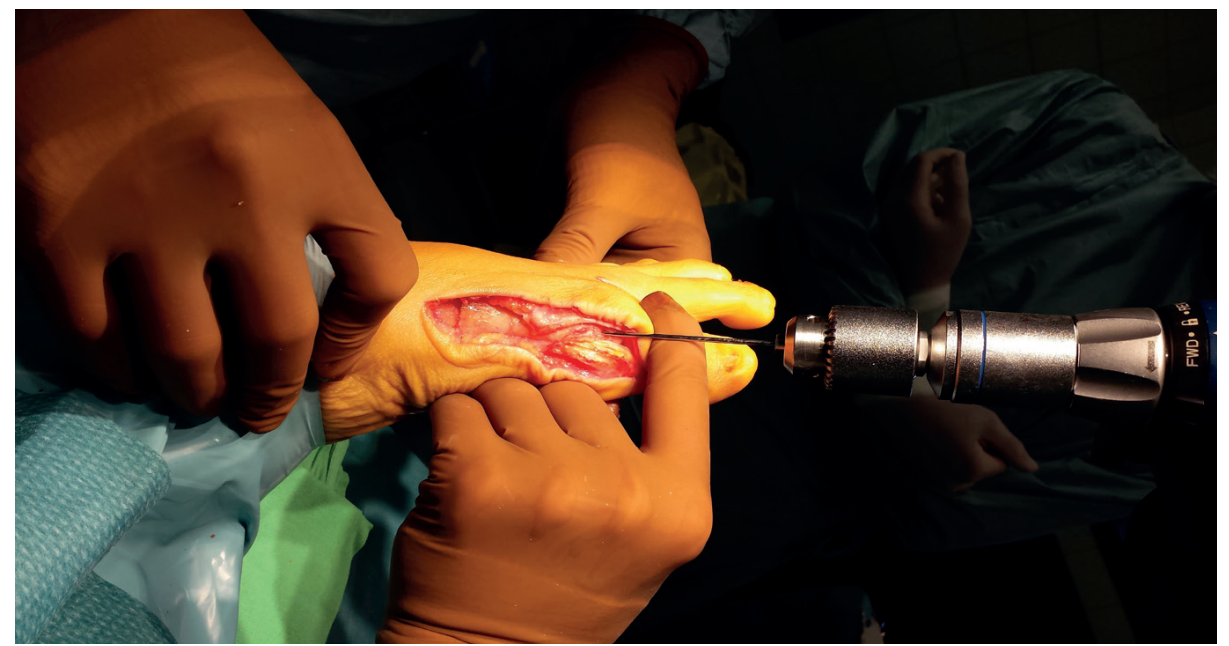

4. ábra Tüzés korrigált helyzetben

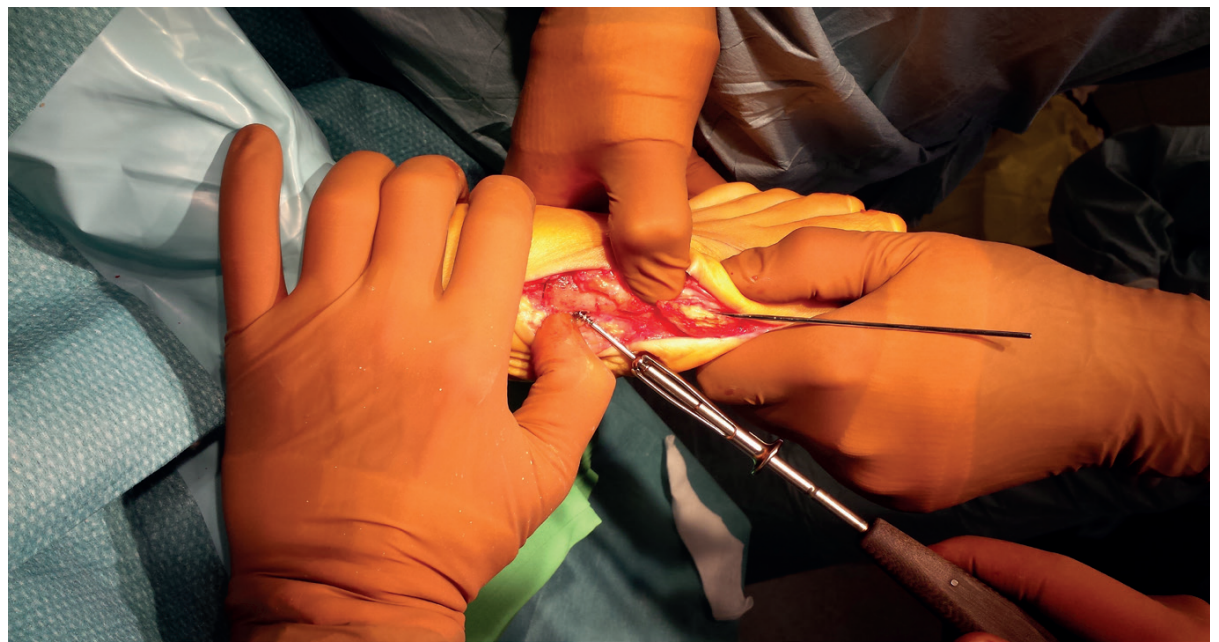

5. ábra Csavarozás 2-3 spongiosa csavarral

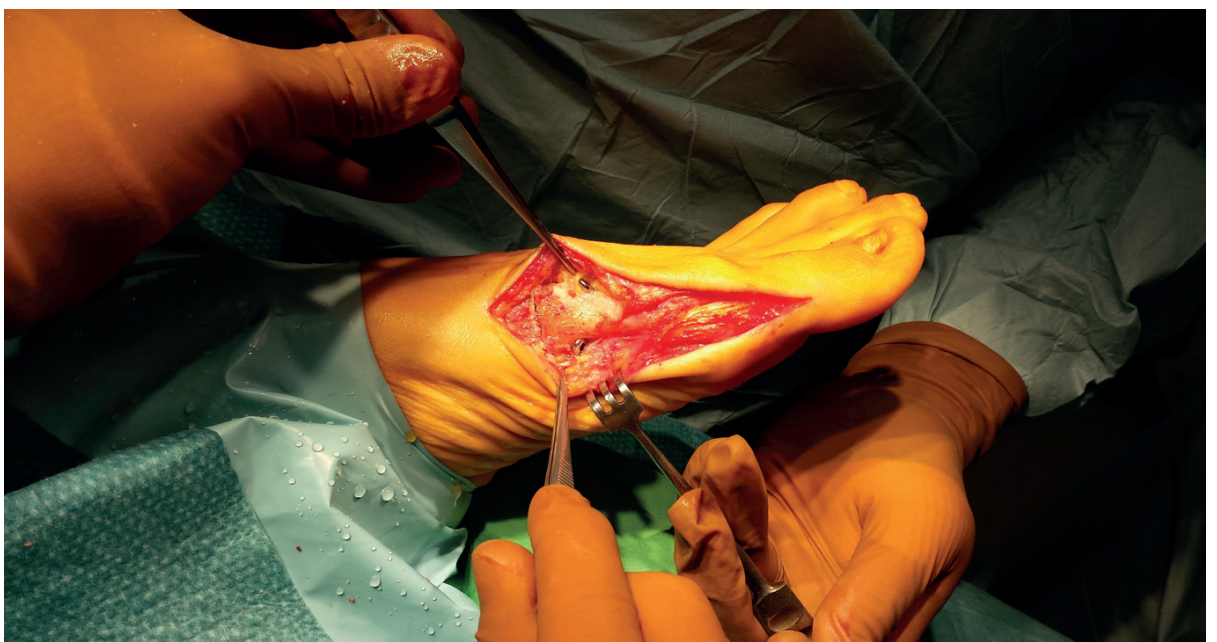

6. ábra MTC desis csavarokkal 


\section{EREDMÉNYEK}

Az IMA preoperatív értéke $17,6^{\circ}\left(15-24^{\circ}\right)$, posztoperatív $8,2^{\circ}\left(1-10^{\circ}\right)$, míg a HVA preoperatív $45,3^{\circ}\left(26-70^{\circ}\right)$, posztoperatív $11,7^{\circ}$ $\left(0-25^{\circ}\right)$. Primer mútétek esetében preoperatív IMA $17,7^{\circ}\left(15-24^{\circ}\right)$, posztoperatív $7,92\left(1-10^{\circ}\right)$, HVA preoperatív értéke $43,2^{\circ}\left(26-70^{\circ}\right)$, posztoperatív értéke $8,9^{\circ}\left(0-25^{\circ}\right)$. Revíziós mútétek esetén IMA preoperatív értéke $17,2^{\circ}$ $\left(16-19^{\circ}\right)$, posztoperatív értéke $9,2^{\circ}\left(8-10^{\circ}\right)$, míg a HVA preoperatív értéke $52^{\circ}\left(45-58^{\circ}\right)$, posztoperatív $20,7^{\circ}\left(10-30^{\circ}\right)$. A különbség a preoperatív és posztoperatív értékeket illetően mind az IMA mind a HVA tekintetében jelentősnek bizonyult (7-8. ábrák).

$\mathrm{Az}$ IMA korrekciója primer mútéteknél $9,78^{\circ}$, revíziós esetekben $8^{\circ}$, a HVA primer mútéteknél $34,3^{\circ}$, míg revíziós esetekben $31,3^{\circ}$. Számottevő különbséget nem észleltünk a primer vagy revíziós mútéti ellátás során a szögértékek javulása tekintetében.

A szezámcsontok subluxatiója mútét előtt 10 esetben $75 \%$ feletti, 7 esetben $50-75 \%$ közötti volt, mútét után pedig minden esetben $50 \%$ alatt.

A betegek szubjektív véleményét az American Orthopaedic Foot and Ankle Society (AOFAS) pontrendszere segítségével értékeltük. Vizsgáltuk a betegek véleménye alapján a fájdalom, funkció és az I. sugár állásának változását, 0-100 pontig értékeltük. Jelentős javulást észleltünk, az eredmény 46-ról (12-65) 93-ra (88-100) emelkedett (9-10. ábrák). Szövődmények vonatkozásában a korai posztoperatív szakban egy esetben sebgyógyulási zavar lépett fel, amely antibiotikus terápiára spontán gyógyult.

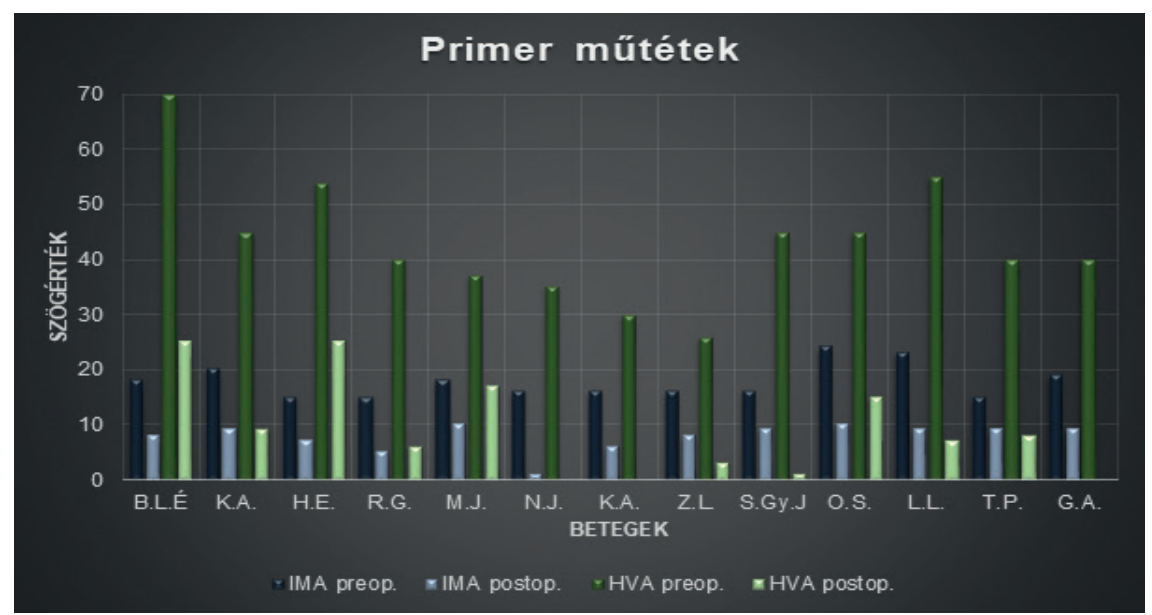

7. ábra Lapidus mütét utáni eredmények primer esetben



8. ábra Lapidus mütét utáni eredmények revíziós esetben 

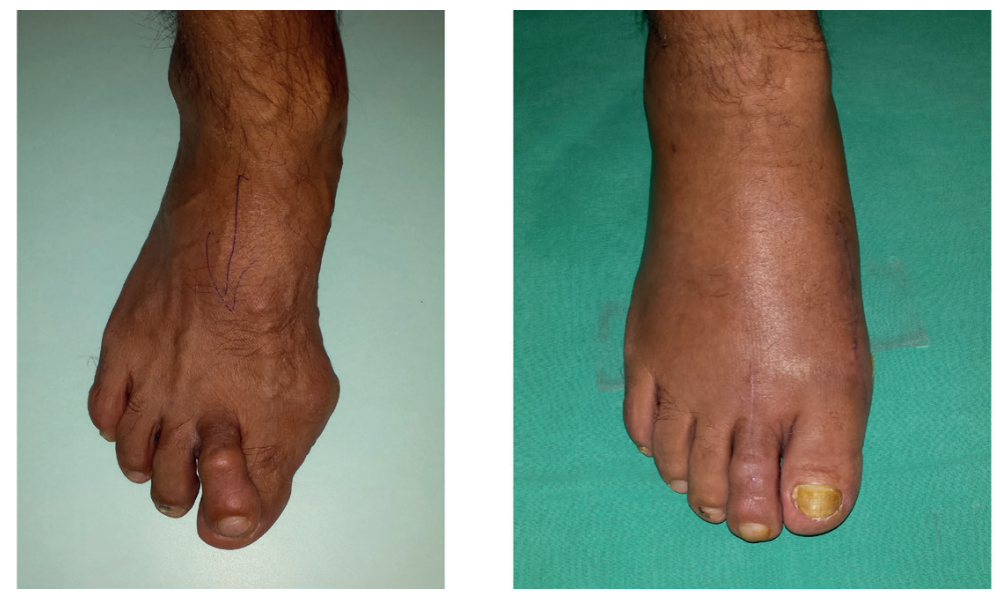

9. ábra Z. L. preoperativ és posztoperativ felvételek


10. ábra L. L. preoperativ és posztoperativ röntgen IMA és HVA értékekkel

\section{MEGBESZÉLÉS}

A mútéti stratégia tervezésénél fontos figyelembe venni a hallux valgus patomechanizmusát. Az I. sugár lazaságának fogalmát 1928-ban Morton vezette be, majd később Lapidus mutatott rá a hallux valgus és az I. sugár lazasága közötti összefüggésre (4). A metatarsocuneiformis (MTC) ízület lazasága a metatarsus primus varus létrejöttében kulcsszerepet játszik, hisz az I. MTP ízületben a metatarsus és hallux deviációját sem csontos, sem lágyrész struktúra nem képes megakadáIyozni (4).

A lazaság és az ebből eredő deviáció létrejöttének megszüntetésében a szerzők az MTC arthrodesis kialakításában látták a megoldást (4).
Eredetileg 1911-ben Albrecht írta le ezt a mútéti megoldást, majd 1925-ben Truslow módosította MTC ízületi ék reszekcióval és elmerevítéssel (5). 1930-ban Lapidus ismertette a róla elnevezett mútéti eljárást, amely MTC ízületi desis a II. metatarsus (MT) desisével, valamint I. MT fej dorsomedialis csontnövedékének levésése és distalis lágyrész egyensúly helyreállítása. Lapidus véleménye szerint a deformitás csúcsa és a megoldás kulcsa az I. MTC ízületben rejlik (5). Az évek során Lapidus nevével fémjelzett mútéti technika számos módosításon esett át.

Fontos említést tenni arról, hogy miként tudjuk az I. sugár lazaságát vizsgálni. A leginkább elfogadott módszer Root, illetve Roukis és társai nevéhez fúződik (5). Root módszerében 
a boka és subtalaris ízület neutralis helyzetben van, rögzíti a II-V. MT fejeket és az I. MT fejet dorsalis és plantaris irányba nyomja. Egy hüvelykujjnyi szélességet meghaladó dorsalis irányú elmozdulás pozitív tesztet eredményez $(11,12)$. Roukis és társai szerint a „dynamic Hicks test" alkalmazható a hypermobilitás megítélésére. Hasonlóan pozícionált láb mellett az öregujjat maximális dorsalflectalt helyzetben tartja, majd plantaris és dorsalis irányba nyomja a I. MT fejet (13).

Lapidus mútét javasolt I. sugár patológiás lazasága esetén, középsúlyos vagy súlyos hallux valgusnál, amennyiben az IMA $15^{\circ}$-ot meghaladja, MTC ízületi degeneratív betegségben, korábbi insufficiens osteotomiák revíziójaként, hallux limitus és metatarsus primus elevatus esetén MTP ízület decompressiójára. Kontraindikált rövid I. sugár esetén, mert további rövidülést eredményezne a mútét, juvenilis hallux valgusnál és fiatal sportolókban (5). Ellenjavallt továbbá aktív gyulladásnál, diabeteses neuropathiás láb esetén (Charcot-láb), MTP ízületi arthrosis mellett, valamint a várható együttműködés hiánya esetén a beteg részéről (15).

Hallux valgus korrekciós mútét tervezésénél célunk kell, hogy legyen az öregujj valgus állásának és pronált helyzetének megszüntetése, az I. MT varus helyzetének korrekciója, MTP ízület tengelyének, ízületi congruentiának és így a funkciónak a helyreállítása, a láb izom-ín egyensúly kialakítása és a fájdalom megszüntetése. Számos irodalmi adattal egyetértésben a probléma kulcsfontosságú részének az MTC ízület instabilitása, lazasága tekinthető $(4,5)$. A módosított Lapidus eljárás stabilizálja az I. MTC ízületet és így az I. sugarat, amivel csökkenti a többi MT fejre eső terhelést. Fontos kiemelni azonban, hogy önmagában a MTC desis nem elegendő. Minden esetben szükséges a lágyrész egyensúly beállítása a MTP ízületben. Ezt az $\mathrm{m}$. adductor hallucis leválasztással, lateralis tokbemetszéssel, medialis tok raffolásával és az m. abductor hallucis ín medializálásával érhetjük el. Megfelelő indikátora a lágyrész balance helyreállásának a szezámcsontok pozíciójának korrigálódása.

Több szerző ajánlását is figyelembe véve középsúlyos és súlyos hallux valgus és elégtelen korábbi osteotomiát követő lábdeformitás esetén alkalmaztuk a módosított Lapidus mútétet $(1,5)$. Kiemelkedően jó eredményeket kaptunk mindkét csoportban mind az objektív radiológiai eredményeket nézve, mind a szubjektív funkcionális pontrendszer tekintetében. Nem találtunk érdemi különbséget a primer mútéti ellátás és a revíziós beavatkozások eredményei között. A szakirodalomban lehetséges szövődményként említett I. sugár rövidülést elkerülendő, 11 esetünkben a MTC ízület reszekált felszínei közé porctalanított spongiosa 'korongot' helyeztünk, amely a hossz megtartásában és a megfelelő csontos átépülés és desis létrejöttében is nagy szerepet játszott.

Számos szerző számolt be Lapidus desis után elhúzódó csontgyógyulásról és álízület kialakulásáról (14). Irodalmi adatok szerint az álízület kialakulásának az esélye 0-5,3\% közé esik $(3,6,8)$. Javasolják a szögstabil minilemezek alkalmazását, mert ezek használata mellett az álízület kialakulásának veszélye tovább csökken $(3,6)$. Beteganyagunkban álízület nem alakult ki a spongiosa plasztikának, 6 hetes tehermentesítésnek és gondos műtéti technikának köszönhetően. Azonban a szögstabil rendszerek használata véleményünk szerint is korai mobilizálást engedélyez, javítva ezzel a beteg funkciójának gyors javulását.

Összegzésként elmondhatjuk az eseteink alapján, hogy a módosított Lapidus technika kiváló eljárás a metatarsus primus varussal járó hallux valgus megoldásában mind elsődleges mútéti eljárásként, mind korábbi insufficiens osteotomiák revíziójaként. 


\section{IRODALOM}

1. Blitz N.: Why the Lapidus bunionectomy is the best procedure for severe bunions. Podiatry Today, 2011. 24. (12): 44-49.

2. Bussewitz B. W., Levar T., Hyer C.: Modern techniques in hallux abducto valgus surgery. Clin. Podiatr. Med. Surg. 2011.28. 287-303. $\mathrm{https://doi.org/10.1016/i.cpm.2011.03.005}$

3. Coetzee J.C., Wickum D. The Lapidus procedure: a prospective cohort outcome study. Foot Ankle Int. 2004. 25. (8): 526-531. https://doi.org/10.1177/107110070402500803

4. Coughlin M. J., Saltzman C. L., Anders R. B., Mann R. A., Saunders W. B.: Mann's surgery of the foot and ankle. 9. ed. New York etc. Saunders/Elsevier, 2014. Ch. 6. 155-307. p.

5. DiDomenico L. A., Wargo-Dorsey M.: Lapidus bunionectomy: First metatarsal-cuneiform arthrodesis. Southerland. Ch. 31. 322-330. $p$.

6. Kopp F. J., Patel M. M., Levine D. S., Deland J. T.: The modified Lapidus procedure for hallux valgus: a clinical and radiographic analysis. Foot Ankle Int. 2005. 26. (11): 913-917. https://doi.org/10.1177/107110070502601103

7. Nix S., Smith M., Vicenzino B.: Prevalence of hallux valgus in the general population: a systematic review and metaanalysis. J. Foot Ankle Res. 2010. 3: 21. https://doi.org/10.1186/1757-1146-3-21

8. Patel S., Ford L. A., Etcheverry J., Rush S. M., Hamilton G.. A: Modified Lapidus arthrodesis: rate of nonunion in 227 cases. J Foot Ankle Surg. 2004. 43. (1): 37-42. https://doi.org/10.1053/i.jfas.2003.11.009

9. Perrera A. M., Mason L., Stephens M. M.: The pathogenesis of hallux valgus. J. Bone Joint Surg. Am. 2011. 93-A: 16501661. https://doi.org/10.2106/JBJS.H.01630

10. Richter M.: Aktualisierte leitlinien Fuß und Sprunggelenk. Fuss Sprung. 2010. 8: $268-287$. https://doi.org/10.1016/i.fuspru.2010.08.003

11. Root M. L., Orien W. P., Weed J. H.: Muscle function of the foot during locomotion. In: Root M. L., O'Rien W. O. P., Weed J. H. (eds.): Clinical biomechanics. Vol. 2. Los Angeles, CA: Clinical Biomechanics Corporation. 1977.

12. Root M. L., Orien W. P., Weed J. H. et al.: Technique for the examination of the first ray. In: Root S. A. (ed.): Biomechanical examination of the foot. Vol. 1. Los Angeles, CA. Clinical Biomechanics. 1971. 80-87. p.

13. Roukis T. S., Landsman A. S.: Hypermobility of the first ray: a critical review of the literature. J. Foot Ankle Surg. 2003. 6: 377-390. https://doi.org/10.1053/i.jfas.2003.09.010

14. Sangeorzan B. J., Hansen S. T.: Modified Lapidus procedure for hallux valgus. Foot Ankle. 1989. 9: 262-266. https://doi.org/10.1177/107110078900900602

15. Toolan B. C.: Surgical strategies: The Lapidus procedure. Foot Ankle Int. 2007. 28. (10): $1108-1114$. https://doi.org/10.3113/FAl.2007.1108

16. Wülker N., Mittag F.: The teatment of hallux valgus. Deutsch. Arztebl. Int. 2012. 109. (49): 857-868.

\section{Dr. Samu Dénes}

SzSzBMK, Jósa András Kórház

4400, Nyíregyháza, Szent István u. 68.

E-mail: somgeza1977@gmail.com 